\title{
Application of low dose of equine chorionic gonadotropin at acupoint Hou Hai for fixed-time artificial insemination in beef cows
}

\section{Aplicação de baixa dose de gonadotrofina coriônica equina no acuponto Hou Hai em protocolos de inseminação artificial em tempo fixo para vacas de corte}

\author{
Monna Lopes de Araujo; ${ }^{1}$ Claudinéia Silva Mendes²; Carmo Emanuel Almeida \\ Biscarde $^{3}$; Fernando Henrique Almeida Biscarde ${ }^{4}$; Laiara Fernandes Rocha ${ }^{5}$; Laura \\ Nicole Filipin da Costa ${ }^{6}$; Maicon Pereira Lents ${ }^{1}$; Ana Lúcia Almeida Santana \\ Larissa Pires Barbosa ${ }^{8 *}$
}

\begin{abstract}
This study evaluated the efficiency application of low dose of equine chorionic gonadotropin (eCG) using Hou Hai acupoint for fixed-term artificial insemination (FTAI) in beef cows. Seventy cows received intravaginal devices with progesterone, and $3 \mathrm{mg}$ of estradiol benzoate on day zero (D0) of FTAI. On D9, the devices were removed, and $150 \mu \mathrm{g}$ of prostaglandin F2 $\alpha$ was applied; the animals were then randomly distributed to three treatment groups: T1 $(n=23), 300$ IU of eCG intramuscularly (IM); T2 ( $(n=23), 90 \mathrm{IU}$ of eCG at acupoint Hou Hai; and T3 $(n=25), 90 \mathrm{IU}$ of eCG at false acupoint IM. On D10, the animals received $1 \mathrm{mg}$ of gonadotropin-releasing hormone IM, and FTAI was performed, $52 \mathrm{~h}$ after the devices were removed. The quantitative variables with normal distribution were assessed using analysis of variance at $5 \%$ probability. For variables that did not show normal distribution, KruskalWallis test at $5 \%$ probability was used. No significant difference was noted among the groups $(P>0.05)$ for the interval between device withdrawal at ovulation $(58.2 \pm 12.2 \mathrm{~h})$, diameter of the largest follicle on D9 $(9.9 \pm 2.2 \mathrm{~mm})$, diameters of the ovulatory follicle $(12.2 \pm 3.0 \mathrm{~mm})$ and the second largest follicle $(6.7 \pm 2.1 \mathrm{~mm})$, follicular growth rate $(0.8 \pm 0.3 \mathrm{~mm} / \mathrm{d})$, ovulation rate $(82 \%)$, corpus luteum size $(2.32$ $\left.\pm 0.35 \mathrm{~cm}^{2}\right)$, and pregnancy rate $(58.67 \%)$. The protocol cost per animal was US\$ 10.67 (T1) and US\$ 8.50 (T2 and T3). The use of 90 IU of eCG applied at Hou Hai acupoint or at false acupoint caused satisfactory synchronization of estrus in beef cows. In addition, this procedure was cost-effective.
\end{abstract}

Key words: Corpus luteum. Follicular dynamics. Pharmacopuncture.

\footnotetext{
1 Discentes de Doutorado, Programa de Pós-Graduação em Ciência Animal nos Trópicos, Universidade Federal da Bahia, UFBA, Salvador, BA, Brasil.E-mail: monnalopes@hotmail.com; maicon_pl@hotmail.com

2 M.e em Ciência Animal, Universidade Federal do Recôncavo da Bahia, UFRB, Cruz das Almas, BA, Brasil. E-mail: caumendes18@gmail.com

3 Dr. em Ciência Animal nos Trópicos, UFBA, Salvador, BA, Brasil. E-mail: ceabiscarde@yahoo.com.br

4 Discente em Medicina Veterinária, UFRB, Cruz das Almas, BA, Brasil. E-mail: fcbiscarde@hotmail.com

5 Discente de Mestrado, Programa de Pós-Graduação em Ciência Animal, UFRB, Cruz das Almas, BA, Brasil. E-mail: laiarafr@, gmail.com

6 Discente de Mestrado, Programa de Pós-Graduação em Ciência Animal nos Trópicos, UFBA, Salvador, BA, Brasil. E-mail: lauranicolefc@hotmail.com

${ }^{7}$ Prof $^{-}$, Universidade Federal dos Vales do Jequitinhonha e Mucuri, UFVJM, Unai, MG, Brasil. E-mail: zootecana@gmail.com

Profa, UFRB, Cruz das Almas, BA, Brasil. E-mail: larissa@ufrb.edu.br

* Author for correspondence
} 


\section{Resumo}

Avaliou-se a eficiência da aplicação de subdose gonadotrofina coriônica equina (eCG) utulizando como via de administração o acuponto Hou Hai em protocolos de inseminação artificial em tempo fixo (IATF) para vacas de corte. Setenta vacas receberam no dia zero (D0) do protocolo dispositivos intravaginais com progesterona, e $3 \mathrm{mg}$ de benzoato de estradiol. No D9 foram retirados os dispositivos, aplicado $150 \mu \mathrm{g}$ de prostaglandina F2 $\alpha$ e distribuídos os animais aleatoriamente em três tratamentos: T1 (n=23) - 300UI de eCG por via intra muscular (IM); T2 (n=23) - 90UI de eCG no acuponto Hou Hai e T3 $(\mathrm{n}=25)$ - 90UI de eCG em falso acuponto, IM. No D10 os animais receberam $1 \mathrm{mg}$ de GnRH por via IM e foi realizada a IATF, 52 horas após a retirada dos dispositivos. Para as variáveis quantitativas com distribuição normal foi utilizada ANOVA, a 5\% de probabilidade. Para as variáveis que não apresentaram distribuição normal, utilizou-se o teste de Kruskal-Wallis, a 5\% de probabilidade. Não houve diferença $(\mathrm{P}>0,05)$ para o intervalo entre a retirada do dispositivo à ovulação $(58,2 \pm 12,2 \mathrm{~h})$, diâmetro do maior folículo no D9 $(9,9 \pm 2,2 \mathrm{~mm})$, diâmetros do folículo ovulatório $(12,2 \pm 3,0 \mathrm{~mm})$ e do segundo maior folículo $(6,7 \pm 2,1 \mathrm{~mm})$, taxa de crescimento folicular $(0,8 \pm 0,3 \mathrm{~mm} / \mathrm{d})$, taxa de ovulação $(82 \%)$, área de corpo lúteo $\left(2,32 \pm 0,35 \mathrm{~cm}^{2}\right)$ e taxa de prenhez $(58,67 \%)$. O custo do protocolo por animal foi de US\$ 10,67 (T1) e US\$ 8,50 (T2 e T3). Sugere-se que a utilização de 90UI de eCG aplicada no acuponto Hou Hai ou em falso acuponto foram satisfatórios na sincronização de estro de vacas de corte. Além disso, possibilita a redução do custo do protocolo.

Palavras-chave: Corpo lúteo. Dinâmica folicular. Farmacopuntura.

\section{Introduction}

Fixed-term artificial insemination (FTAI) involves the use of hormonal protocols to control follicular development and ovulation; it allows insemination without the need of estrus detection, ovarian overstimulation, and embryo transfer recipient synchronization, and hence leads to higher reproductive efficiency (PIRES et al., 2004). Most of the ovulation synchronization protocols for bovine species involve the use of gonadotropinreleasing hormone $(\mathrm{GnRH})$ and estradiol $\left(\mathrm{E}_{2}\right)$, along with progesterone-releasing devices $\left(\mathrm{P}_{4}\right)$ (BÓ; BARUSELLI, 2014). Of the many hormones used to perform FTAI in dairy and dairy herds, $\mathrm{P}_{4}$ and estradiol benzoate (EB) are used in the initial phase, to synchronize the emergence of the follicular wave. In the intermediate phase, the $\mathrm{P}_{4}$ device is removed, and PGF2 $\alpha$ is applied to ensure luteolysis. In the final phase, luteinizing hormone (LH) and/ or follicle stimulating hormone (FSH) and EB are applied $24 \mathrm{~h}$ after the removal of $\mathrm{P}_{4}$, to synchronize and induce ovulation (BO et al., 2002). Ovulation can also be induced by administering GnRH or LH $12 \mathrm{~h}$ before FTAI (MARTINEZ et al., 2002).
In addition, equine chorionic gonadotropin (eCG) can be administered in the intermediate phase of the protocol, to stimulate the final follicular growth until ovulation (SOUMANO, PRICE, 1997).

As an alternative to stimulating follicular growth, gonadotropins, including eCG, may be included in the synchronization protocols at the time of the removal of the exogenous source of $\mathrm{P}_{4}$ (BARUSELLI et al., 2004a; SOUZA et al., 2009). Improvement in the fertility of cows treated with eCG can be explained by three effects: eCG can increase the preovulatory follicle diameter at the time of FTAI, improve ovulation rate, and increase plasma progesterone concentration during the subsequent luteal phase (SÁ FILHO et al., 2010a). When administered in anestrous cows, eCG creates conditions to stimulate follicular growth and ovulation, even in cows that have compromised endogenous release of gonadotrophins. Its use has been shown to have a positive effect on herds with a low rate of cyclicity (anestrus), for example, in animals that had recently calved (postpartum less than 2 months), those with a compromised body condition $(\leq 2.5$ on a scale of 1 to 5 ; BARUSELLI et 
al., 2004b), and those with impaired dominant follicle growth, owing to the high levels of progesterone at the end of the ovulation synchronization treatment, which leads to increased ovulation and pregnancy rates (BARUSELLI et al., 2004a).

At present, there is no consensus regarding the best dose of eCG to be used in FTAI protocols for beef and/or dairy cows. Different doses ranging from 300 to $800 \mathrm{IU}$ of eCG have been reported (SOUZA et al., 2009; BRYAN et al., 2010). However, the lowest effective dose of eCG for estrous synchronization in FTAI is not yet known.

Rocha et al. (2007) compared the effect of no eCG treatment (control) and two doses of eCG (200 and 300 IU) on the FTAI efficacy in Nelore cows and showed that the highest pregnancy rates were obtained with the use of eCG (pregnancy rate: $22.2 \%, 42.1 \%$, and $44.0 \%$ for control, $200 \mathrm{IU}$ eCG, and $300 \mathrm{IU}$ eCG, respectively; $P<0.05)$. However, no difference $(P>0.05)$ in pregnancy rates was noted between the two doses of eCG, and the lowest effective dose was recommended. Doroteu et al. (2015) also evaluated the effect of two different doses of eCG on the pregnancy rate of lactating Nelore cows at 35 to 75 postpartum days, and found no differences in the pregnancy rate for animals receiving 200 or $300 \mathrm{IU}$ of eCG on day (D) 8 of the synchronization protocol for FTAI (200 IU, 62.1\%; $300 \mathrm{IU}, 78.4 \% ; P>0.05)$.

Acupuncture involves the stimulation of specific points in the body by using objects such as needles, hands, and rods in order to achieve a therapeutic or homeostatic effect (PRADIPTO, 1986). It is an ancient Chinese technique; however, its history and origin are controversial. With the discovery of stone needles, human acupuncture was assumed to have begun at the end of the Neolithic period $(16,000$ 4,000 BC). Gold and silver acupuncture needles were recovered from the tomb of Lieu Scheng, who died about 200 BC. References to veterinary acupuncture history is as old as human acupuncture history (DRAEHMPAEHL; ZOHMANN, 1994). In
Sri Lanka, about 3,000-year-old treaty was found, in which is the mention of the use of acupuncture in Indian elephants. Around 650 BC, Sun Yang was considered to be the first acupuncturist dedicated to Veterinary Medicine (ALTMAN, 1997).

Injection of substances via acupuncture, called pharmacopuncture, is an interesting option for acupuncture in animals, since it requires a short period of treatment and few materials such as hypodermic needles and hormones and medications (FARIA, 2008). The stimuli induced to the acupoints linked to reproductive organs promote changes in the plasma levels of $\mathrm{LH}, \mathrm{FSH}, \mathrm{E}_{2}$, and $\mathrm{P}_{4}$. Two theories have been proposed to explain the mechanisms of acupuncture in reproduction. The first theory suggests that the stimulus promotes the release and action of endorphins in the hypothalamic-pituitarygonadal axis, causing a temporary depression in the secretion of LH, wherein, after the cessation of the stimulation, the hypophysis becomes more reactive to $\mathrm{GnRH}$ and returns to equilibrium. The second is that the stimulus promotes the production and release of adrenaline, catecholamines, estrogens, and growth factors, causing direct effects on the paracrine and autocrine gonadal control of steroidogenesis (LIN et al., 2006).

Some hormonal protocols associated with pharmacopuncture for reducing hormone doses and consequently the cost of protocols showed the same level of efficacy as that of traditional protocols, as described by Simplício (2008), who worked with goats and sheep, and by Cardoso et al. (2018) and Souza et al. (2019), who worked with goats. Komatsu et al. (1998) showed that the Hou Hai acupoint can be used to induce estrus in zebu cows via the needling stimulus. Researchers are becoming interested in pharmacopuncture and its use in veterinary practice to promote the reduction of the indis criminate use of drugs, reduce the adverse effects, prevent the appearance of residues in animals intended for consumption, and minimize the cost of treatments. 
However, information on the effective hormonal doses for pharmacopuncture in beef cows is lacking. Hence, this study aimed to evaluate the efficiency of eCG application at the Hou Hai acupoint in the synchronization protocols of FTAI for improving the reproductive performance of beef cows.

\section{Material and Methods}

\section{Experimental site}

The study was performed in two experimental stages at different times. The project was approved by the Committee on Ethics in the Use of Animals (CEUA) of the Federal University of Bahia (UFBA), filed under number 342015 .

The first experiment was conducted in the spring season, at the Sector of Bovinocultura de Corte of the Federal University of Recôncavo da Bahia (UFRB), on the campus of Cruz das AlmasBahia (12³9'54.9" South, 3904'36.9" West), from October to November 2015. The site is at an altitude of $195 \mathrm{~m}$ above sea level and has a humid tropical climate, with mean temperature of $24.5^{\circ} \mathrm{C}$, relative humidity of $80 \%$, and average annual rainfall of $1170 \mathrm{~mm}$.

The second experiment was also conducted in the spring season at the Boa Esperança Farm located in Nova Soure-Bahia $\left(38^{\circ} 29^{\prime} 36.9^{\prime \prime}\right.$ South, $11^{\circ} 14^{\prime} 00^{\prime \prime}$ West), from November to December 2015. The site has an altitude of $169 \mathrm{~m}$ above sea level and humid tropical climate, with average temperature of $27.5^{\circ} \mathrm{C}$, relative humidity of $67 \%$, and average annual rainfall of $970 \mathrm{~mm}$.

\section{Animals}

Seventy adult non-lactating cows with an average body condition score of $3.62 \pm 0.69$ were used, according to Nicholson and Butterworth (1986); they were previously selected through clinical-gynecological evaluation by using transrectal ultrasonography by using a $6 \mathrm{MHz}$ linear transducer (AquilaVet scanner; Pie Medical ${ }^{\mathrm{TM}}$, the Netherlands). The animals were kept in an extensive rearing system in Brachiaria pasture (Brachiaria decumbens), and provided water and mineral salt ad libitum.

In the first stage, 22 non-lactating adult Nelore cows with a mean body condition score of 3.56 \pm 0.58 were useds; in the second stage, 48 nonlactating adult Nelore cows with a mean body condition score of $3.62 \pm 0.58$ were useds.

\section{Hormonal protocol and experimental design}

All cows received new progesterone slowreleasing intravaginal devices (PRIMER $^{\mathrm{TM}}$; Tecnopec, Brazil) containing $1 \mathrm{~g}$ of $\mathrm{P}_{4}$ and $3 \mathrm{mg}$ of EB (Estrogin ${ }^{\mathrm{TM}}$; Biofarm, Brazil) at D0 of the protocol. On D9, the devices were removed, and the animals were randomly distributed in three treatments groups: $\mathrm{T} 1(\mathrm{n}=22)$, application of 150 $\mu \mathrm{g}$ of a synthetic analog of PGF2 $\alpha$, D-cloprostenol (Prolise $^{\mathrm{TM}}$, Arsa, Argentina) and 300 IU (100\% dose) of eCG (Novormon ${ }^{\mathrm{TM}}$, Syntex, Argentina), both intramuscularly (IM); T2 ( $=23)$, application of $150 \mu \mathrm{g}$ of D-cloprostenol IM and $90 \mathrm{IU}$ (30\% of the dose) of eCG applied at Hou Hai acupuncture point; and T3 $(\mathrm{n}=25)$, application of $150 \mu \mathrm{g}$ D-cloprostenol and 90 IU of eCG applied IM in the semitendinosus muscle of the pelvic limbs, considered as false acupoint. At D10, all animals received $1 \mathrm{mg}$ of GnRH (Gestran Plus ${ }^{\mathrm{TM}}$, Argentina) IM, and FTAI was performeds, $52 \mathrm{~h}$ after the $\mathrm{P}_{4}$ device was withdrawn.

The hormones were applied at the Hou Hai acupoint by using a $16 \mathrm{G}$ intravenous catheter having an internal diameter of $1.3 \mathrm{~mm}$, external diameter of $1.7 \mathrm{~mm}$, and length of $45 \mathrm{~mm}$; the angle of needle insertion was $45^{\circ}$, perpendicular to the insertion point, and covered the entire depth of the catheter tube. Before the hormone applications, povidone-iodine (RIODEINE ${ }^{\mathrm{TM}}$ ) was applied IM in the semitendinosus muscle of the animals. 
The Hou Hai acupoint is located in the depression between the medial distance of the ventral base of the tail and the anus (LIN et al., 2006). Anatomically, Hou Hai is located between the coccygeal muscle and the anal sphincter and includes the innervation of the caudal rectal nerve (figure 1). This point can be accessed by inserting the needle in an angular position in cattle and in the perpendicular position in small animals, with depth varying from 3 to 18 $\mathrm{cm}$, according to the size of the animal (HWANG; LIMEHOUSE, 2006).

\section{Variables evaluated and methodology adopted}

The interval between the withdrawal of the intravaginal device to ovulation $(\mathrm{h})$ was evaluated in the first experimental stage. Furthermore, the size of the largest follicle at D9 $(\mathrm{mm})$; size of the largest follicle at ovulation $(\mathrm{mm})$; size of the second largest follicle at ovulation $(\mathrm{mm})$; follicular growth rate of the dominant follicle $(\mathrm{mm} / \mathrm{d})$; area of the corpus luteum $\left(\mathrm{CL} ; \mathrm{cm}^{2}\right)$; percentage of normal CL (\%) and CL cavity (\%); and pregnancy rate (\%) were evaluated. For this, after the device was removed, the ovaries were monitored using transrectal ultrasonographic evaluations every $24 \mathrm{~h}$, up to $24 \mathrm{~h}$ after the detection of ovulation.

In the second stage, the area of CL, CL types (normal and cavity), and pregnancy rate were evaluated. The CLevaluation in both the experimental stages was performed 9 days after the removal of the intravaginal device by using ultrasonographic evaluation, and gestation was diagnosed 30 days after the FTAI by using transrectal ultrasonography.

The efficiency of the ovulation synchronization protocol was evaluated using the pregnancy rate. The costs of the protocols were determined by considering the exchange rate between Brazilian real (R\$) and the US dollar (US\$), according to the commercial dollar quotation published by the Brazilian Central Bank, and calculated on the basis of the retail value of the hormones obtained from the City of Feira de Santana-Ba (Table 1).

Table 1. Cost in dollars (\$) of hormones used for ovulation synchronization in cows, in the city of Feira de SantanaBA, in June 2015.

\begin{tabular}{lccccc}
\hline Hormones & $\mathbf{P}_{4}$ & $\mathbf{B E}$ & $\mathbf{P G F}_{2} \boldsymbol{\alpha}$ & $\mathbf{G n R H}$ & eCG \\
\hline Price per box / package (\$) & 45.16 & 9.16 & 11.30 & 35.48 & 54.50 \\
\hline Preço por dose (\$) & 4.51 & 0.37 & 0.75 & 1.77 & $\mathrm{~T} 1=3.27 ; \mathrm{T} 2 \mathrm{e} \mathrm{T3}=1.10$ \\
\hline
\end{tabular}

$\mathrm{P}_{4^{-}}$progesterone; BE- Estradiol; $\mathrm{PGF}_{2} \boldsymbol{\alpha}$ - prostaglandin; GnRH- gonadotrophin releasing hormone; eCG- equine chorionic gonadotrophin. Quotation and conversion of the real (R\$) to the US dollar (US\$) made on the website of the Central Bank of Brazil. Value of one dollar in the month of June $2015=3.10$ reais.

\section{Statistical analysis}

The farm effect between the two experimental stages and the normality of the data were evaluated using the Shapiro-Wilk test. For the quantitative variables that showed normal distribution, analysis of variance at $5 \%$ probability was used. For the variables that did not show normal distribution, Kruskal-Wallis test at 5\% probability was used [SPSS version 21 (1989-2012)].

\section{Results and Discussion}

No difference in follicular growth and ovulation moment was noted between treatments $(P>0.05$; Table 2). The interval between device withdrawal and ovulation was similar $(P>0.05)$ between the groups (Table 2), with mean of $58.20 \pm 12.21 \mathrm{~h}$, indicating that the reduced eCG dose used could efficiently promote ovulation within the expected time for cows subjected to hormonal protocols. 
This variable needs to be studied in ovulation synchronization protocols to determine the best time to perform AI; the recommended time is $52 \mathrm{~h}$ after the withdrawal of the devices.

Table 2. Follicular growth and ovulation time evaluated in beef cows submitted to different ovulation synchronization protocols.

\begin{tabular}{|c|c|c|c|c|}
\hline Variables & T1 & T2 & T3 & Average \\
\hline Interval withdrawn from ovulation device (h) ${ }^{1}$ & $72.3 \pm 13.6$ & $51.3 \pm 35.0$ & $51.0 \pm 32.5$ & $58.2 \pm 12.2$ \\
\hline Diameter of the follicle on day 9 (D9) (mm) ${ }^{1}$ & $12.5 \pm 0.4$ & $8.5 \pm 0.5$ & $8.7 \pm 0.5$ & $9.9 \pm 2.2$ \\
\hline Larger diameter pre ovulatory follicle $(\mathrm{mm})^{1}$ & $15.8 \pm 0.3$ & $10.2 \pm 0.7$ & $10.8 \pm 0.7$ & $12.2 \pm 3.0$ \\
\hline Diameter second largest follicle $(\mathrm{mm})^{1}$ & $9.1 \pm 0.3$ & $6.0 \pm 0.5$ & $5.0 \pm 0.4$ & $6.7 \pm 2.1$ \\
\hline Follicular growth rate $(\mathrm{mm} / \mathrm{d})^{1}$ & $1.2 \pm 0.8$ & $0.5 \pm 0.5$ & $0.8 \pm 0.8$ & $0.8 \pm 0.3$ \\
\hline Ovulation rate $(\%)^{2}$ & $7 / 7(100 \%)$ & $5 / 7(71 \%)$ & $6 / 8(75 \%)$ & $82.0 \pm 15.7$ \\
\hline
\end{tabular}

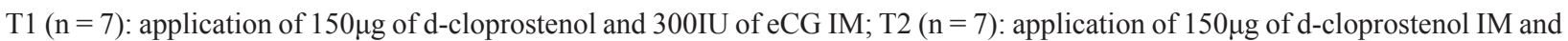
90IU of eCG in Hou Hai acupoint; T3 $(\mathrm{n}=8)$ : application of $150 \mu \mathrm{g}$ of d-cloprostenol and 90IU of eCG IM (false acupoint). There was no difference between treatments, ${ }^{1}$ ANOVA and ${ }^{2}$ Kruskal Wallis $(\mathrm{P}>0.05)$

The mean diameter of the largest follicle at D9 was $9.90 \pm 2.25 \mathrm{~mm}(P>0.05)$. According to Sá Filho et al. (2010b), the diameter of the dominant follicle has a positive correlation with ovulation rate, and consequently gestation after FTAI in Bos indicus females, whose behavior was observed in the present study (Table 2). Our results corroborate those described in the literature by other researchers, such as Morotti et al. (2013) who obtained follicle diameter at D9 of $11.7 \pm 2.0 \mathrm{~mm}$ by using $300 \mathrm{IU}$ of eCG in FTAI protocols. Sá Filho et al. (2010a) who reported follicular diameter of $11.1 \pm 0.3 \mathrm{~mm}$ in cows submitted to FTAI protocols; and Edwards et al. (2014) who reported follicular diameter of 10.5 $\pm 0.1 \mathrm{~mm}$ in Bos taurus cows.

The eCG doses and application routes used in this study did not influence $(P>0.05)$ the sizes of the largest $(12.27 \pm 3.07 \mathrm{~mm})$ and the second largest follicles $(6.70 \pm 2.14 \mathrm{~mm})$ at the time of ovulation, follicular growth rate $(0.08 \pm 0.35 \mathrm{~mm} /$ day), and ovulation rate ( $82 \%$; Table 2$)$, indicating the efficacy of the doses applied at both the Hou Hai and false acupuncture points in triggering endocrine processes in the hypothalamic-pituitary-ovary axis for follicular growth and ovulation.
Oliveira et al. (2007) also found no differences in these variables in beef cows administered eCG or FSH in FTAI protocols and showed a mean diameter of the largest and second largest follicles of $9.63 \pm 1.54 \mathrm{~mm}$ and $7.20 \pm 1.14 \mathrm{~mm}$, respectively; ovulatory follicle growth rate of $0.07 \pm 0.04 \mathrm{~mm} / \mathrm{h}$; and ovulation rate of $83.33 \%$. These values are similar to those obtained in the present study.

Measuring the mean size of the dominant follicle, as well as the interval between device withdrawal and ovulation, is important since the ovulatory capacity of follicles in animals is known to be responsive to the preovulatory peak of LH. In a study by Gimenes et al. (2008), it was found that $33 \%$ of Bos indicus females had ovulation with follicle diameters between 7.0 and $8.4 \mathrm{~mm}$ and that LH responsiveness increased when follicles reached diameters between 8.5 and $10.0 \mathrm{~mm}(80 \%)$ and greater than $10.0 \mathrm{~mm}(90 \%)$.

The most recent studies have indicated that eCG can effectively stimulate follicle growth, ovulation, and luteinization mediated by the increased availability of LH (MURPHY, 2012; TORRESJÚNIOR et al., 2016). Which, consequently, may result in acceptable pregnancy rates after FTAI in 
cows (SALES et al., 2011), as well as in heifers (SÁ FILHO et al., 2010b) treated with 400 IU in $\mathrm{P}_{4}$ device removal, which was also observed in present study, even using eCG dose much lower than that studied by Sá Filho et al. (2010b).

Cardoso et al. (2018) used 30\% eCG dose at the Hou Hai acupoint for the synchronization of estrus and ovulation, and obtained a follicular growth rate of $2.14 \pm 0.09 \mathrm{~mm} /$ day, mean diameter of the largest follicle of $7.39 \pm 0.16 \mathrm{~mm}$, and mean diameter of the second largest follicle of $5.83 \pm 1.56 \mathrm{~mm}$. Biscarde et al. (2012) obtained follicular growth rate of $0.8 \pm 0.4 \mathrm{~mm} /$ day, and $1.3 \pm 1.3 \mathrm{~mm} /$ day, using hormonal doses at the Bai Hui acupoint and false acupoint in sheep, respectively, suggesting the efficiency of using hormonal doses associated with pharmacopuncture even in other species.

No farm effect was observed on the variables of CL and body type, as well as on the gestation rate; therefore, these data were evaluated together, and the results showed that the treatments applied to the different groups of cows did not influence $(P>0.05)$ the abovementioned variables (Table 3), with mean values for CL area of $2.32 \pm 0.35$, occurrence of normal CL and cavity, and gestation rate of $58.67 \%$.

Table 3. Area, type of corpus luteum and diagnosis of gestation evaluated in beef cows submitted to different ovulation synchronization protocols.

\begin{tabular}{lcccc}
\hline Variables & T1 & T2 & T3 & Average \\
\hline Luteal body area $\left(\mathbf{c m}^{2}\right)^{\mathbf{1}}$ & $2.66 \pm 1,45$ & $2.34 \pm 1.35$ & $1.96 \pm 1.75$ & $2.32 \pm 0.35$ \\
Normal corpus luteum $(\mathbf{\%})^{\mathbf{2}}$ & $13 / 22(60 \%)$ & $19 / 23(82 \%)$ & $10 / 25(40 \%)$ & $60.67 \pm 21.01$ \\
Cavitary corpus luteum $(\mathbf{\%})^{\mathbf{2}}$ & $5 / 22(23 \%)$ & $1 / 23(4 \%)$ & $7 / 25(28 \%)$ & $18.33 \pm 12.66$ \\
Pregnancy rate $(\mathbf{\%})^{2}$ & $15 / 22(68 \%)$ & $12 / 23(52 \%)$ & $14 / 25(56 \%)$ & $58.67 \pm 8.33$ \\
\hline
\end{tabular}

T1 ( $\mathrm{n}=22)$ : application of $150 \mu \mathrm{g}$ of d-cloprostenol and 300II of eCG IM; T2 ( $=23)$ : application of $150 \mu \mathrm{g}$ of d-cloprostenol IM and 90IU of eCG in Hou Hai acupoint; T3 ( $\mathrm{n}=25)$ : application of $150 \mu \mathrm{g}$ of d-cloprostenol and 90IU of eCG IM (false acuponto). There was no difference between treatments, ${ }^{1}$ ANOVA and ${ }^{2}$ Kruskal Wallis (P>0.05). The presence of CL in 4 (T1), 3 (T2) and 8 (T3) animals was not observed.

Interestingly, the area of luteal bodies formed after ovulation was similar between the experimental groups, since the reduction in eCG dose from 300 to $90 \mathrm{IU}$ did not impair ovulation and formation of such a structure, which is remarkably important in maintaining pregnancy in cows. According to Luttgenau et al. (2011), the quality of CL influences the plasma concentration of progesterone, considering that they are directly related variables, indicating that females with smaller luteal bodies may have compromised production of progesterone, and consequently gestation rate. However, Loiola et al. (2014) did not observe any influence of CL area on the pregnancy rate in bovine recipients. Measuring the progesterone dosage was not possible in this study; however, the gestation rate was not compromised in any of the experimental groups, suggesting that the formed CLs were fully functional.

The present study evaluated the occurrence of cavitary (18\%) and non-cavitary (60\%) CL in cows of the three experimental groups (Table 3); the occurrence of cavitary CL has already been reported (LEMOS et al., 2010). Cavitary CL is caused by the incomplete occupation of the follicular cavity by the cells during luteinization. Moreover, according to Kito et al. (1986), the presence of a cavity in the $\mathrm{CL}$ in cattle does not affect gestation, even when this cavity is greater than $15 \mathrm{~mm}$ and/or persists for long periods (20 days to 4 months). Cavities have even been observed in the luteal bodies of pregnant $(86 \%)$ and non-pregnant females (77\%). In non- 
pregnant women, this cavity tends to disappear with the estrus cycle.

Silva etal.(2018) studied the relationship between ovulatory follicle diameter, CL area, and pregnancy rate in beef cows submitted to FTAI and obtained a luteal body with a mean area of $2.04 \pm 0,22 \mathrm{~cm}^{2}$ in the group of pregnant females, similar to the rate observed in this study; these values are similar than those obtained in the present study. Silveira et al. (2012) used Nelore cows synchronized for FTAI and reported pregnancy rates of $53 \%$; in addition, Tortorella et al. (2013) used 400 IU of eCG in the FTAI protocol for beef cows to evaluate the effect on gestation rate, among other variables, and obtained a $52 \%$ pregnancy rate for a group of treated females. These results are similar to those obtained in this study; however, Tortorella et al. (2013) used eCG dose higher than that used in the present study. In addition to the lower dose used in this study, the pregnancy rate obtained in all treatments was within the range expected for Nellore cows, as described by Sá Filho et al. (2010b).

Morotti et al. (2013) using a standard protocol for IATF obtained a $45.4 \%(10 / 22)$ gestation rate, lower than that found in both treatments of the present study when using only $30 \%$ of the eCG dose (Table $3)$. In a study with the caprine species, Cardoso et al. (2018) also used $30 \%$ of the hormonal dosage commonly used in the synchronization protocol, but administered the dose at the acupuncture Hou Hai or IM and obtained $70.6 \%$ and $85.7 \%$ pregnancy rate, respectively. These results suggest that reduced doses of eCG can be used in hormonal protocols without affecting their efficiency.

The cost of protocols per animal was $\$ 10.67$ for T1 and $\$ 8.50$ for T2 and T3 (Table 4), with a $20.34 \%$ reduction in the value of the $100 \%$ dose group compared to those in which $30 \%$ of the total dose of eCG was used.

Table 4. Cost of ovulation synchronization protocol for beef cows, dollar quotation (\$).

\begin{tabular}{lccc}
\hline Parameter & T1 $(\mathbf{n}=\mathbf{2 2})$ & T2 $(\mathbf{n = 2 3})$ & T3 $(\mathbf{n}=\mathbf{2 5})$ \\
\hline Cost $/$ Protocol per animal $(\$)$ & 10.67 & 8.50 & 8.50 \\
\hline
\end{tabular}

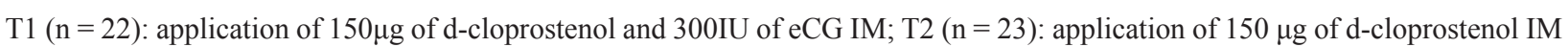
and 90IU of eCG in Hou Hai acupoint; T3 $(n=25)$ : application of $150 \mu \mathrm{g}$ of d-cloprostenol and 90IU of eCG IM (false acuponto).

The application of hormonal doses of eCG ( 90 IU), corresponding to $30 \%$ of the dose commonly used in FTAI protocols for beef cows, applied at Hou Hai acupuncture and false acupoint was efficient in inducing follicular growth and promoting ovulation, as revealed by improvements in follicular growth, ovulation time, CL area, and gestation rate. Our findings suggest that using the false acupoint to apply the dose used would be more practical and less costly. Future studies need to be performed to check the efficacy of using even lower doses of eCG, since our results suggest that the doses currently used in beef cows are overestimated.

\section{References}

ALTMAN, S. Acupuncture therapy in small animal practice. The compendium in continuing education, v.19, n.11, p.1233-1245, 1997.

BARUSELLI, P. S.; MADUREIRA, E. H.; MARQUES, M. O.; RODRIGUES, C. A.; NASSER, L. F. T.; SILVA, R. C. P.; REIS, E. L.; SÁ FILHO, M. F. Efeito do tratamento com eCG na taxa de concepção de vacas Nelores com diferentes escores de condição corporal inseminadas em tempo fixo (análise retrospectiva). Acta Scienciae Veterinariae, Porto Alegre v. 32, p. 228, 2004a. Suplemento.

BARUSELLI, P. S.; REIS, E. L.; MARQUES, M. O.; NASSER, L. F.; BO, G. A. The use of hormonal treatments to improve reproductive performance of anestrous beef cattle in tropical climates. Animal Reproduction Science, Amsterdam, v. 82-83, n. 1, p. 479-486, 2004b. DOI: 
10.1016/j.anireprosci.2004.04.025

BISCARDE, C. E. A.; BARBOSA, L. P.; SOUZA, D. O.; ROMERO, D. C. M.; FERREIRA, A. B.; ARAÚJO, R. C. S. A.; ALMEIDA, V. F.; DUTRA, P. A. Crescimento folicular e ovulação de cabras com aplicação hormonal no acuponto Bai Hui. In: CONGRESSO BRASILEIRO DE ZOOTECNIA, Cuiabá. Anais... Cuiabá, 2012. p. 1-3.

BÓ, G. A.; BARUSELLI, P. S. Synchronization of ovulation and fixed-time artificial insemination in beef cattle. Animal, Westport, v. 8, p. 144-150, 2014. Supplement 1. DOI: 10.1017/S1751731114000822

BO, G. A.; BARUSELLI, P. S.; MORENO, D.; CUTAIA, L.; CACCIA, M.; TRIBULO, R.; MAPLETOFT, R. J. The control of follicular wave development for self appointed embryo transfer programs in cattle. Theriogenology, Stoneham, v. 57, n. 1, p. 53-72, 2002. PMID: 11775981.

BRYAN, M. A.; BÓ, G. A.; HEUER, C.; EMSLIE, F. R. Use of equine chorionic gonadotrophin in synchronised AI of seasonal-breeding, pasture- based, anoestrous dairy cattle. Reproduction, Fertility and Development, Melbourne, v. 22, n. 1, p. 126-131, 2010. DOI: 10.1071/ RD09225

CARDOSO, R. C.; BARBOSA, L. P.; SOUZA, R. S.; FRANÇA, C. S.; RIBEIRO JUNIOR, M. D. M.; SANTANA, A. L. A.; JESUS, R. D. L.; SANTOS, R. S. Application of hormonal subdoses at acupoint Hou Hai in estrus synchronization protocols of goats. Semina: Ciências Agrárias, Londrina, v. 39, n. 3, p. 1135-1142, 2018. DOI: $10.5433 / 1679-0359.2018 v 39 n 3 p 1135$

DOROTEU, E. M.; OLIVEIRA, R. A.; PIVATO, I. Avaliação de diferentes doses de eCG nas taxas de prenhez em vacas Nelore lactantes ressincronizadas e submetidas à IATF. Rev. Brasileira Saúde Produção Animal, Salvador, v.16, n. 2, p. 449-457, 2015. DOI: 10.1590/S1519-99402015000200019

DRAEHMPAEHL, D.; ZOHMANN, A. Acupuntura no cão e no gato: princípios básicos e prática científica. São Paulo: Roca, 1994. 245 p.

EDWARDS, S. A. A.; ATKINSON, P. C.; SATAKE, N.; BOE-HANSEN, G.; MCGOWAN, M. R. Ovarian dynamics in response to two modified intravaginal progesterone releasing device and estradiol benzoate base the ovulation synchronisation protocols designed for use in Brahman heifers. Animal Reproduction Science, Amsterdam, v. 148, n. 1-2, p. 18-25, 2014. DOI: 10.1016/j.anireprosci.2014.05.005

FARIA, A. B. de. A farmacopuntura com xilazina para sedação em cães. Dissertação (Mestrado em Ciências Veterinárias), Universidade Federal de Uberlândia, Uberlândia, 2007. 37p.
GIMENES, L. U.; SA, M. F.; CARVALHO, N. A. T.; TORRES, J. R. S.; SOUZA, A. H.; MADUREIRA, E. H.; TRINCA, L. A.; SARTORELLI, E. S.; BARROS, C. M.; CARVAlHO, J. B. P.; MAPletOFT, R. J.; BARUSELLI, P. S. Follicle deviation and ovulatory capacity in Bos indicus heifers. Theriogenology, Stoneham, v. 69, n. 7, p. 852-858, 2008. DOI: 10.1016/j. theriogenology.2008.01.001

HWANG, Y. C.; LIMEHOUSE, J. B. Atlas de acupuntura canina. In: SCHOEN, A. M. Acupuntura veterinária: da arte antiga à moderna. São Paulo: ROCA, 2006. cap. 9, p. 122-146.

KITO, S.; OKUDA, K.; MIYAZAWA, K.; SATO, K. Study on the appearance of the cavity in the corpus luteum of cows by using ultrasonic scanning. Theriogenology, Stoneham, v. 25, n. 2, p. 325-333, 1986. DOI: 10.1016/0093-691X(86)90068-3

KOMATSU, S.; SAITO, S.; EGAWA, D. Research of acupuncture point (Hou Hai) in bovine on the index value of reproductive efficiency and puncture method. The Tohoku. Jornal Veterinary Clinics, Morioka, v. 21, n. 1, p. 1-5, 1998. DOI: 10.4190/jjvc1990.21.1

LEMOS, L. S.; BENEDITTO, A. P. M. D.; CARVALHO, E. C. Q. Primeira descrição de corpo lúteo cavitário gestacional em Sotalia guianensis (Van Bénéden, 1864) relato de caso. Revista Brasileira de Ciência Veterinária, Rio de Janeiro, v. 17, n. 2, p. 83-86, 2010. DOI: 10.4322/ rbcv.2014.149

LIN, J. H.; CHAN, W. W.; WU. L. S. Acupuntura para tratar distúrbios reprodutivos. In: SCHOEN, A. M. Acupuntura veterinária: da arte antiga à moderna. São Paulo: ROCA, 2006. cap. 21, p. 258-264.

LOIOLA, M. V.G.; PEREIRA, D.F.C.; VASCONCELOS, L. V.; LIMA, M. C. C.; FERRAZ, P. A.; RODRIGUES, A. S.; BITTENCOURT, R. F.; JESUS, E. O.; RIBEIRO FILHO, A. L. Pregnancy rate of bovine embryo recipients treated with a GnRH analogue at the time of embryo transfer. Revista Brasileira de Saúde Produção Animal, Salvador, v. 15 , n. 3, p. 782-789, 2014. DOI: 10.1590/ S1519-99402014000300025

LUTTGENAU, J.; ULBRICH, S. E.; BEINDORFF, N.; HONNENS, A.; HERZOG, K.; BOLLWEIN, H. Plasma progesterone concentrations in the midluteal phase are dependent on luteal size, but independent of luteal blood flow and gene expression in lactating dairy cows. Theriogenology, Stoneham, v. 125, n. 1-4, p. 20-29, 2011. DOI: 10.1016/j.anireprosci.2011.02.002

MARTINEZ, M. F.; KASTELIC, J. P.; ADAMS, G. P.; MAPLETOFT, R. J. The use of a progesterone-releasing device (CIDR-B) or melengestrol acetate with GnRH, 
$\mathrm{LH}$, or estradiol benzoate for fixed-time AI in beef heifers. Journal of Animal Science, Oxford, v. 80, n. 7, p. 1746-1751, 2002. DOI: 10.2527/2002.8071746x

MOROTTI, F.; CAMPOS, J. T.; SENEDA, M. M. Fixed-time artificial insemination using injectable progesterone: ovarian follicular dynamics and pregnancy rates of Nelore cows (Bos indicus) with and without a corpus luteum. Semina: Ciencias Agrárias, Londrina, v. 34, n. 6, p. 386-387, 2013. DOI: 10.5433/1679-0359.2013v34n6Supl2p3867

MURPHY, B. D. Equine chorionic gonadotropin: an enigmatic but essential tool. Animal Reproduction, Belo Horizonte, v. 9, n. 3, p. 223-230, 2012.

NICHOLSON, M. J.; BUTTERWORTH, M. H. $A$ guide to condition scoring of zebu cattle. Addis Ababa: International Livestock for Africa, 1986.29 p.

OLIVEIRA, A.F.; NASCIMENTO, A.V.; TORRES, A.A.C.; DIAS, M.; PAULINO, M. F.; PENITENTE, J. M. Dinâmica folicular na sincronização de ovulação associada à administração de FSH-p em vacas da raça Nelore. Acta Scientiae Veterinariae, v.35, p. s1119, 2007. Suplemento 3.

PIRES, V. A.; ARAUJO, C. R.; MENDES, Q. C. Fatores que interferem na eficiência reprodutiva de bovinos de corte. In: SIMPÓSIO PECUÁRIA INTENSIVA NOS TRÓPICOS, 2004, Piracicaba. Anais... Piracicaba: Fundação de Estudos Agrários Luiz de Queiroz, 2004. p. 355-398.

PRADIPTO, M. J. Zen shiatsu- equilibrio energético e consciência do corpo. São Paulo: Summus, 1986. 183 p.

ROCHA, J. M.; RABELO, M. C.; SANTOS, M. H. B.; MACHADO, P. P.; BARTOLOMEU, C. C.; NEVES, J. P.; LIMA, P. F.; OLIVEIRA, M. A. L. IATF em vacas Nelore: avaliação de duas doses de eCG e reutilização de implantes intravaginais de progesterona. Medicina Veteterinária, Recife, v. 1, n. 1, p. 40-47, 2007.

SÁ FILHO, M. F.; AYRES, H.; FERREIRA, R. M.; MARQUES, M. O.; REIS, E. L.; SILVA, R. C. P.; RODRIGUES, C. A.; MADUREIRA, E. H.; BÓ, G. A.; BARUSELLI, P. S. Equine chorionic gonadotropin and gonadotropin releasing hormone enhance fertility in a norgestomet-based, timed artificial insemination protocol in suckled Nellore (Bos indicus) cows. Theriogenology, Stoneham, v. 73, n. 5, p. 651-658, 2010a. DOI: 10.1016/j. theriogenology.2009.11.004

SÁ FILHO, M. F.; CRESPILHO, A. M.; SANTOS, J. E. P.; PERRY, G. A.; BARUSELLI, P. S. Ovarian follicle diameter at timed insemination and estrous response influence likelihood of ovulation and pregnancy after estrous synchronization with progesterone or progestin- based protocols in suckled Bos indicus cows. Animal Reproduction Science, Amsterdam, v. 120, n. 1-4, p. 2330, 2010b. DOI: 10.1016/j.anireprosci.2010.03.007

SALES, J. N. S.; CREPALDI, G. A.; GIROTTO, R. W.; SOUZA, A. H.; BARUSELLI, P. S. Fixed-time AI protocols replacing eCG with a single dose of FSH were less effective in stimulating follicular growth, ovulation, and fertility in suckledanestrus Nelore beef cows. Animal Reproduction Science, Amsterdam, v. 124, n. 1-2, p. 1218, 2011. DOI: 10.1016/j.anireprosci.2011.02.007

SILVA, M. A., RODRIGUES, A. S., BRANDÃO, T. O., MAGGITTI JUNIOR, L. D. P., CARÔSO, B. S., CHALHOUB, M., BITTENCOURT, R. F; RIBEIRO FILHO, A. L. Avaliação morfofuncional do corpo lúteo para diagnóstico precoce de gestação 20 dias após IATF em vacas mestiças leiteiras. Pesquisa Veterinária Brasileira, Rio de Janeiro, v. 38, n. 10, p. 2006-2011, 2018. DOI: $10.1590 / 1678-5150-p v b-5413$

SILVEIRA, E. C.; BORTOLLOTI, L. A.; MOROTTI, F.; SENEDA, M. M. Perfil plasmático de progesterona e taxa de prenhez de bovinos nelore sincronizados com novo dispositivo intravaginal de progesterona (BIOCOWGEST ${ }^{\circledR}$ ). Revista Acadêmica: Ciências Agrárias e Ambientais, Curitiba, v. 10, n. 1, p. 73-79, 2012. DOI: 10.7213 /academica. 7532

SIMPLÍCIO, A. A. Estratégias de manejo reprodutivo como ferramenta para prolongar o período de oferta de carnes caprina e ovina no Brasil. Tecnologia e Ciência Agropecuária, João Pessoa, v. 2, n. 3, p. 29-39, 2008.

SOUMANO, K.; PRICE, C. A. Ovarian follicular steroidogenic acute regulatory protein, low- density lipoprotein receptor, and cytochrome P450 side-chain cleavage Messenger ribonucleic acids in cattle undergoing superovulation. Biology Reproducion, Oxford, v. 56, n. 2, p. 516-522, 1997. DOI: 10.1095/biolreprod56.2.516

SOUZA, A. H.; VIECHNIESKI, S.; LIMA, F. A.; SILVA, F. F.; ARAUJO, R.; BO, G. A.; WILTBANK, M. C.; BARUSELLI, P. S. Effects of equine chorionic gonadotropin and type of ovulatory stimulus in a timedAI proto- col on reproductive responses in dairy cows. Theriogenology, Stoneham, v. 72, n. 1, p. 10-21, 2009. DOI: 10.1016/j.theriogenology.2008.12.025

SOUZA, D. O.; ARAUJO, M. L.; BISCARDE, C. E. A.; MENDES, C. S.; SILVA, M. A. A.; ROMERO, D. C. M.; CARDOSO, B. M.; SANTANA, A. L. A.; BARBOSA, L. P. Use of hormonal subdoses applied in Bai Hui acupuncture in estrus synchronization protocols for goats. Semina: Ciências Agrárias, Londrina, v. 40, n. 4, p. 1501-1512, 2019. DOI: 10.5433/1679-0359.2019v4 0n4p1501 
TORRES-JÚNIOR, J. R. S.; RIBEIRO, D. L. S.; PEREIRA, H. G.; FRANÇA, I. G. Mitos e verdades em protocolos de IATF. Revista Brasileira de Reprodução Animal, Belo Horizonte, v. 40, n. 4, p. 129-141, 2016.

TORTORELLA, D. R.; FERREIRA, R.; TONELLOTTO, S. J.; SILVEIRA, A. O.; BARRETA, M. H.; OLIVEIRA,
J. F.; BAYARD, G. A. P.; PEREIRA, N. J. The effect of equine chorionic gonadotropin on follicular size, luteal volume, circulating progesterone concentrations, and pregnancy rates in anestrous beef cows treated with a novel fixed-time artificial insemination protocol. Theriogenology, Stoneham, v. 79, n. 8, p. 1204-1209, 2013. DOI: 10.1016/j.theriogenology.2013.02.019 
